\title{
A Political Dilemma in Higher Educational Reform
}

Should the Communist Party have a political and constitutional presence in private education institutions?

\section{Limin Bai}

\section{OpenEdition}

\section{Journals}

Édition électronique

URL : http://journals.openedition.org/chinaperspectives/1116

DOI : 10.4000/chinaperspectives. 1116

ISSN : 1996-4617

Éditeur

Centre d'étude français sur la Chine contemporaine

\section{Édition imprimée}

Date de publication : 15 février 2005

ISSN : 2070-3449

Référence électronique

Limin Bai, « A Political Dilemma in Higher Educational Reform », China Perspectives [En ligne], 57 | january - february 2005, mis en ligne le 01 février 2008, consulté le 28 octobre 2019. URL : http:// journals.openedition.org/chinaperspectives/1116; DOI : 10.4000/chinaperspectives.1116

Ce document a été généré automatiquement le 28 octobre 2019

(C) All rights reserved 


\title{
A Political Dilemma in Higher Educational Reform
}

\author{
Should the Communist Party have a political and constitutional presence \\ in private education institutions?
}

\section{Limin Bai}

1 Should the Chinese Communist Party (CCP) have a political and constitutional presence in an institution of private tertiary education? This is a critical issue regarding the governance structure in the private tertiary education sector. The following article has as its base a survey conducted in Shanghai in 2003, and attempts to identify the problems regarding the role of the Party in the private tertiary education sector, and to suggest solutions that could enhance the leadership of the Party ${ }^{1}$.

2 The major differences between the public and private tertiary education sectors lie in both the governing and resource funding structures. In the public sector, the Party oversees higher education institution governance, and its leadership is assured by the Constitution. The legal status of a private education institution is often a corporation, and the Board of Trustees administers the financial issues, determines policies for the operation and control of the institute, and appoints a president responsible for management. Constitutionally the Party is not part of the governing body. This difference is associated with funding: the public sector is largely funded by the government while the private sector has to find its own funding and must survive in a competitive market. However, politically and ideologically, the Party's control over education in both sectors is absolute.

Reform in the higher education sector has seen the flourishing of private tertiary education, where capitalist methods have been gradually employed in financing and administration. However, the topic of the role of Party representatives in the management of private educational institutions remains taboo. While China's current political system is still communist at its heart, the finance system and administrative structure in private tertiary education are rather more capitalist in nature. Such a conflict appears to challenge the Party's control of education and has given rise to a number of questions: What is the socialist nature of China's private education? Should 
private education be allowed to be profit-making? What organisations should be responsible for the supervision of private educational institutions? Should legal avenues, rather than the Party, regulate this industry? These questions all point to a critical issue: how far could China's private education develop, if capitalist methods are employed to run it, and the Party's current role remains unchanged?

4 So far there has been little open discussion on the leadership of the Party in the private education sector, and how the Chinese government could employ the rule of law to regulate and supervise it while entirely respecting its autonomy. For researchers outside China, the development and expansion of the private education sector are fascinating'; many educational organisations have been interested in this large market since China joined the World Trade Organisation. Inside China some researchers and educators have advocated the use of the legal system to promote and expand private education ${ }^{3}$, and there is discussion on 'how to change the administrative role of the Party's.

5 This article will first look at the 'absolute leadership of the Party in education', in order to examine the relationship between the Party and the governing body in a private institution. It will then examine various legal avenues to ensure that private tertiary education providers are in compliance with government policy and regulations.

What is the absolute leadership of the Party in education?

6 The absolute leadership of the Party in education is legislated in the Constitution and in law. The Party has power over political principles, political orientation, decisionmaking on major issues and the appointment of important officials to government bodies. The Party's policies and decisions become the codes of conduct to be observed by the whole society. In short, the Party is the core of leadership of the Chinese socialist course. Within China's political and state systems, the leadership of the Party in education is absolute.

7 There are two lines of authority in the governing body of a government-funded university or higher education institution: a Party line and an administrative line. While the president of a university is the CEO from an administrative perspective, he answers to the Party Secretary. This ensures the Party's leadership in higher education. This administrative structure was established in 1949 when all private educational institutions were abolished or merged into public institutions. The leadership of the Party in public tertiary education is constitutionally assured.

8 In the mid-1980s China's education reform began, and non-governmental education emerged and gradually developed. In 1993 the State Council issued a document, entitled Compendium of Educational Reform and Development in China, which announced measures for further reform. The government would no longer undertake education alone, and welcomed private (or non-governmental) investment in education.

9 In 2002 the Standing Committee of the ninth National People's Congress passed the Non-Governmental Education Promotion Act (NEPA 2002), in which the government emphasised the development of private education: encouragement, support, guidance and supervision in accordance with law $^{5}$. It is within this context that many researchers, in order to help establish proper rules, have drawn upon experiences and lessons from other developed countries, as well as Taiwan, Hong Kong and the history 
of traditional Chinese education. However, no models or experiences could help address the issue of the Party's involvement.

In China, the private education sector is broadly referred to as minban (WW), or the 'non-governmental education', including institutions established and run by both state owned or collective-owned enterprises or organisations, and private enterprises and individuals. Debates on the definition of the term mainly focus on whether the term 'private education' can embrace the various forms of education provider. It has been agreed that non-governmental educational organisations are not all private in nature. The sector actually includes both private and public owners, and a considerable portion of non-governmental schools under non-private ownership. Regardless of the diversity in forms and ownerships, however, these educational organisations have one thing in common: their financial resources do not come from the government's education funds. Therefore, so-called minban or non-governmental education actually refers to non-government-funded education ${ }^{6}$. In the higher education sector, private colleges and institutions emerged in response to the socio-economic demand and this sector has helped ease the pressure on government educational funds.

11 In the field of educational theory as well as economics, the concept of educational enterprises has also been advocated. Although the concept is still controversial, private tertiary education has borrowed many ideas and methods from private enterprises. Some have even argued that education should be run like any other industry? Nevertheless, even these advocators agree that educational enterprises are different from any other type of enterprise because they are people oriented. Because of this difference, some argue that the role of the Party has to be emphasised to ensure the socialist nature of education in the private sector.

12 According to the economist Li Yining, there are three main differences between the private higher education sector and the rest of the private sector. First, private enterprises focus on profits which should not be the main object of educational enterprises. Second, other enterprises' investments are determined by their profits, but educational enterprises cannot operate this way, as the funds anyone donates for educational purposes are not allowed to be withdrawn for other purposes or transferred to other parties. Third, education is a public good, and the assets of educational institutions cannot be used to secure other loans ${ }^{8}$.

13 From the structure of the governing body, there are also three differences. First, the board of trustees in an educational organisation is under the supervision and control of the local government education authority, which has the overall authority over its constitution, regulations and the members of the board, while board directors in an enterprise elect their chairman. Second, the board of trustees consists of educators and people interested in education, with the motivation to serve the public interest, while a board of directors consists of investors whose principle aim is to achieve a profit for their shareholders. Third, all members on the board of trustees have equal voting rights, while on the board of directors the portion of shares one holds determines one's voting rights and the weight of that vote 9 .

14 There is a key difference in leadership structure between private and public education sectors. In a public higher education institution the administrative management is operating under the Party's leadership, while in a private institution The Board of Trustees provides leadership. The Board of Trustees has the authority to supervise and ensure that the president he appointed follows the policy made by the central 
government and the Party, operates the school in accordance with law, and maintains teaching quality. Yet the Board of Trustees may not interfere in the day-to-day running of the school. This governance structure is legislated for in NEPA 2002, which does not mention the position of the Party.

Nevertheless, there are no differences in terms of aims, policies and content of education between public and private education sectors. Private education providers must adhere to the socialist nature of education. According to NEPA 2002, "Nongovernmental education is also a public good and part of socialist education' ${ }^{10}$. In order to enforce this, it requires that 'non-governmental education providers must act in accordance with laws and regulations, follow and carry out government's educational policies, assure teaching quality and devote themselves to the training of various talents for the construction of socialism ${ }^{11}$.

In brief, private education emerged in response to China's rapid economic development and social demand for education, especially for higher education. A major difference between the private and public education sectors lies in their financial resources. An educational organisation with non-government funding can be considered as 'private'. Private education is defined by the Chinese government as part of the socialist education system and public good. So private education is in theory controlled by the Party, although the Party does not have the same constitutional position as that in the public sector.

Mission impossible: a dilemma for the Party cadres in private higher education institutions

With no direct participation by the Party in the management and administration of private institutions, would the rules in NEPA 2002 be overlooked? Should the Party's leadership be understood from a macroscopic perspective rather than simply from a constitutional position? To answer these questions, we need to examine the relationship between the Party and the governing body in a private educational institution.

According to a document issued jointly by the Department of Human Resources of the Central Committee of the Party and the Party Committee of the Ministry of Education in June 2000, the Party's mission in the private education sector can be summarised as the following six objectives: to publicise and carry out the policies defined, to supervise the institutions' administration to ensure that the institutions follow the Party line, adhere to a socialist way of education and are law-abiding; to participate in decision-making in important issues, and support the operation of the institution in accordance with the law; to strengthen the Party ideologically; to show leadership in the institution's political and ideological work and moral education; to show leadership in the institution's mass organisations such as union, student associations and the Youth League, and to carry out United Front work.

These objectives appear to differ little from those in the public education sector. As mentioned earlier, in the public sector the Party's leadership is constitutionally assured 
while in the private sector the Party is not part of the governing body. Would these Party objectives be carried out as they would in the public establishments? The 21 nongovernmental educational institutions surveyed in Shanghai in 2003 (including 14 already established and 7 in the process of becoming established) all have Party representation, but most Party cadres are part-time. For instance, a president or deputy president of the institution is also the secretary of the Party ${ }^{12}$. This common practice has implications for the implementation of Party objectives.

In the public sector, a Party secretary usually focuses only on the Party's political and ideological work. For a part-time Party secretary with a full-time position in senior management in a private institution, his/her organisation's survival is priority. So it is inevitable that the duties of Party secretaries in private educational institutions are often limited to relaying documents from their superiors. In decision-making, they usually fulfil their duties as presidents rather than as Party secretaries. If a Party secretary is not a president or board member, he/she then will have little influence in decision-making.

Ideological work among Party members appears, according to the survey, in name only. Party members in the public sector are affiliated with the Party, which is at the top of the institutional hierarchy. As in other private enterprises, all the employees in a private education institution are hired by private employers; Party members among such staff have thus to identify themselves as employees first and any previous connection with the Party seems to become insignificant.

Under these circumstances Party organisations have found it difficult to organise functions or activities more easily arranged in the public sector. Although Party organisations have been relatively active in moral education and ideological work among students, they do not yet play a significant role in mass organisations. And the Party's United Front work has not yet made it onto the agenda of the Party's organisations in the private education sector ${ }^{13}$. This suggests that without a constitutional role in the private institution it is difficult for the Party to have the same influence as it does in public institutions. Thus the role of the Party in the private sector could become just an empty shell.

Possible avenues: the rule of law

The Party is aware of its weak leadership in the private education sector, so one of the recommendations made by the team which conducted the survey in Shanghai is thatin order to ensure the socialist nature of private education-the government or the Party invest more money to support the establishment of the Party in all nongovernmental education organisations ${ }^{14}$. But, should the government try to endorse a stronger Party presence in the private education sector, or employ the rule of law to regulate and audit the sector?

According to the survey, a principle problem in non-governmental education institutions in Shanghai is a lack of supervision over the board of trustees. When an educational institution seeks approval from the local government, the institution has to set up the board of trustees and constitutional rules. Yet the local government does not continue to monitor and check whether the institution operates according to the rules, and whether the board of trustees works properly. Meanwhile, staff or the board members in a private organisation are often on the move. Under these circumstances democratic supervision of the board and its chairman barely exists, and chairmen of the boards can easily view the educational establishment as their family business. For 
example, instead of operating the institutions through the board in accordance with the constitutional rules, some chairmen employ their own family members to run the institutions ${ }^{15}$. As mentioned earlier, constitutionally, the board of trustees appoints a president to operate teaching and administration; the board and the chairman have the authority to supervise the management and president, but the chairman may not interfere with the president's responsibilities. Yet in reality some chairmen have violated such rules.

Under these circumstances, rather than emphasising the strengthening of the Party's leadership in the private sector in a traditional and narrow sense, government may need to continuously improve the rule of law and employ legal means to assure lawful operation within the private education sector.

Government needs to provide the board of trustees with not only principles but also adequate corporate governance regulations, and then implement adequate auditing and supervisory systems. As the operation of the board of trustees is relatively new to both board members and chairmen, it is necessary to provide all involved with corporate governance training so that they become aware of their rights and responsibilities, know what lawful operation is and know what is illegal. Consequently, board members would be able to stop chairpersons from acting like "family heads", and promote democracy in the operation of the institutions.

In the interest of credibility and integrity of these organisations, the government could encourage the establishment of professional organisations, such as Presidents Committee of Non-Governmental or Private Education, and Association of Private Education, which can become self-regulating and would supervise all the institutions in the sector ${ }^{16}$. The government also needs to encourage the establishment of organisations which conduct independent third-party audits.

34 The above suggestions emphasise control, not by the Party committee, but by the rule of law, a structure that needed for all operational aspects of private institutions, including administration, teaching and finance, etc. If a deputy president, responsible for an institutions' finances, was to misappropriate funds from that institution, then the institution must learn from the experience in order to prevent such illegal acts happening again.

The survey in Shanghai also showed that in all non-governmental institutions the Party has played an active role with regard to political and ideological work among students. Most boards of trustees rely on the Party's organisation to carry out political and ideological work, including appointing teachers in charge of classes or as political advisors ${ }^{17}$. However, well-established regulations would help students to become aware their responsibilities and rights; clear codes of behaviour and norms can also be established to guide students, and self-governing student organisations could be encouraged.

In brief, problems in the current private education sector should not simply be viewed as the result of a lack of Party leadership and supervision. Rather, as many researchers and educators have pointed out, undesirable performance in the private education sector is the consequence of a lack of a comprehensive rule of law and operational regulations. With specific legislation for the non-governmental education sector now in place the sector should be further developed and gradually regulated in accordance with this legislation. 
A new perspective on the Party's role in private tertiary education

In order to strengthen the Party's leadership in private tertiary education, another recommendation from the survey report is that the Party Committee at the higher level may assign full-time cadres to private schools and institutions to carry out the objectives of the Party, and the Party would be responsible for financial costs associated with the cadres ${ }^{18}$. If this suggestion were accepted, it would not become a financial burden for private education providers. However, constitutionally how will these cadres fit into the private organisations? Should they be acknowledged as the Party's commissioners and be on the board of trustees? If so, how will the autonomy of private education providers then be defined and justified?

There are two major differences regarding administration and management between the public and private sectors. Firstly, private educational providers have autonomy in terms of employing teachers and other general staff, salary scales, using and administering the funds, and in equipment. Secondly, the private educational providers at pro-secondary level are able to decide their own curricula according to market demand.

Private education providers have the advantage here, and well-established management and administrative practices in the private sector could later provide valuable experience for guiding further reforms in the public sector. Assigning Party cadres to private education institutions could constitutionally obstruct this process.

This autonomy privilege is also significant in further development of private education. The government has tried attracting all social groups regardless of their political beliefs and backgrounds to invest in education. If the Party assigns special cadres to private institutions, there might be some implications for schools and institutions established by other political parties and groups, as well as those with foreign investments. Consequently, it could impede the development of private education, and hamper the process of internationalisation of education.

This emphasis on autonomous governance in private tertiary education in China may be regarded as calling for the abolishment of the leadership of the Party which, given the political and ideological conditions in China, is definitely unacceptable. Yet the Party's political and constitutional presence in private tertiary institutions is not necessary, a situation borne out by the existence of alternatives that could accommodate the Party's objectives for the sector while entirely respecting the autonomy of these institutions: for instance, all the Party members in private tertiary institutes could be affiliated with the Party Committee of the regional department of education, under the branch of private education. Thus, there would be no constitutional confrontation or overlap with individual private education providers. The Party Committee could focus on the education of its members in terms of law and Party policy in relation to their responsibilities and rights in the private education sector. Party members, including both ordinary employees and presidents or board members, should be encouraged to observe the rule of law and participate in the supervision of the institutions where they work. Moreover, as Party members hail from different institutions, they could exchange information and views, and then would be informed about what is going on in the sector. This would help them to exercise their rights better. Meanwhile, this will assist the government authorities to audit and monitor the private sector in terms of observation of the law and teaching quality. As for helping mass organisations, such as the Youth League, students' association and 
teachers union or associations, the Party could execute its leadership through its members The Party Committee might also assist relevant government departments to resolve disputes between employees and employers.

Can China continue to further reforms without touching its political system?

China's higher education reform is a reflection of the tensions in Chinese society: between a partly capitalist economy, education and society and an unchanged political system. This capitalism-socialism mix was created by Deng Xiaoping who ruled that there should be no debate on the nature of the reform measures, as long as they help China's economic development. Although this capitalist-socialist consolidation is coated in the theory of "socialism with the Chinese characteristics", it is actually a revisiting of the thesis "Chinese learning as substance and Western learning for practical use". It has enabled China to adopt certain Western elements to develop the country's economy and aid technological advancement, without changing the political system. But can China achieve further reforms without touching its political system?

The political and constitutional absence of the Party in private tertiary education will pose no threat to the leadership of the Party. The Party's educational policy and aims are embodied in the law. Therefore, as long as private education providers are operating in accordance with the law, and teaching courses are aligned with government aims and meet regional needs, the absolute leadership of the Party in education is still assured. Any narrow interpretation of the role of the Party in private education will only weaken the implementation of the law, and create hurdles for further developing private education.

Furthermore, to define the Party role in the private tertiary sector is a matter of clarifying the legal status of private education institutions and strengthening the legal framework in which it operates. Emphasis needs to be placed on the elements of the law, according to us, rather than the leadership of the Party, to ensure that the government at all levels truly grant the private education sector autonomy, enabling it to operate according to the needs of social-economic development and of the employment market.

More importantly, the experience and lessons relating to the governance system in the private tertiary education sector would be beneficial for further reforming the administration and management of the public tertiary education sector, such as stipulation of the legal status of higher education institutions. This then requires the Party leadership to re-define its role in education. Only then can the relationship between the government and higher education institutions be re-oriented, so that universities have more autonomy in relation to their financial and academic administration.

The significance of this discussion is not limited to reform in the higher education sector. It reflects the need for wider political reforms. Since 1949 the absolute control of the Party on every aspect of social and political life in China has become "natural"; any opposition to the Party is considered unlawful and is politically and ideologically forbidden. In the past twenty years or so China's economic reforms have led to the incorporation of many capitalist elements into the Chinese matrix of socialism. However, through Deng Xiaoping's upholding of the Four Cardinal Principles, the Party's control remains absolute while capitalism is allowed in the economic sector. This capitalist-socialist consolidation might have worked in the past twenty years, but it cannot accommodate continued expansion. At some point, the Chinese government 
will have to address the demand for political reform. This discussion of the role of the Party and governance in private tertiary education can be seen as a signal for that such changes are a consideration.

\section{NOTES DE FIN}

1. Wu Weimin, unpublished survey on 21 private tertiary organisations, Shanghai jiaoyu kexueyuan, 2003.

2. See James Tooley, Lessons from Private Education in Developing Countries, Stanford, Ca., Hoover Institution Press, 2002.

3. Pan Maoyuan and Wei Yitong, "Lifa sili gaodeng jiaoyu fazhan de baozhang" (Safeguard Private Education by Law), Gaodeng jiaoyu yanjiu (China Higher Education), No. 1, 1996, pp. 20-22; Wu, Yiying et al., "Guanyu jianquan woguo sili gaodeng jiaoyu yunxin jizhi" (On Establishing a Sound Operational Mechanism in Non-Governmental Education), Fujian gaojiao yanjiu (Fujian Higher Education), No. 5, 1996, pp. 19-22; Hu Wei, Minban jiaoyu de fazhan yu guifan (Development and Regulation of NonGovernmental Education), Beijing jiaoyu kexue chubanshe, 2000.

4. At the International Conference on China's Educational Reform in the 21st Century, jointly sponsored by Xiamen University and Hong Kong University, in December 2003, I was informed of the discussions on how to change the administrative role of the Party (Dang de xingzheng zhineng de zhuanhuan).

5. For an outline of the development of China's non-governmental education, see Section of Educational Planning of the Ministry of Education, and The Research Institute of Education in Shanghai, Zhongguo minban jiaoyu lüpishu (Green Paper on nongovernmental education in China), Shanghai jiaoyu chubanshe, 2003, pp. 169-174, pp. 229-236; Hu Dongfang and Jiang, Chunjiao, "Minban" za ban? - Zhongguo minban jiaoyu you silu (Where is the Future - Concerns About China's Non-Governmental Education), Fujian jiaoyu chubanshe, 2001, pp. 31-32.

6. Gu Meilin, Zhongguo minban jiaoyu tansuo (A study on China's Non-Governmental Education), Sichuan jiaoyu chubanshe, 1999, pp. 17-18.

7. "More Money Spent on Education", Beijing Review, Vol. 42, No. 26, June 1999, p. 24.

8. Li Yining, "Lun jiaoyu jingfei de chouji yu yunzuo" (On Educational Funds Raising and Operation), discussed by Gu Meilin in Zhongguo minban jiaoyu tansuo, op. cit., pp. 8-9. 9. This point was made by Wang Zhiqiang, in charge of the non-governmental education sector in the Higher Education Committee. Mr. Wang's view is quoted by Gu Meilin in Zhongguo minban jiaoyu tansuo, op. cit., pp. 9-10.

10. Non-Governmental Education Promotion Act, Chapter 1, Article 3.

11. Ibid, Article 3.

12. Wu Weimin, op. cit.

13. Ibid.

14. Ibid.

15. Ibid. 
16. Chen Guisheng has two proposals on this matter. See his "Minban xuexiao dongshihui wenti - jianlun xuexiao de shehui jiandu yu ziwo jiandu" (The Board of Trustees in Non-Governmental Education - also on society's supervision on schools and schools self-supervision), Minban jiaoyu dongtai (Development in Non-Governmental Education), No. 11, 2000, pp. 35-38; and "Guanyu minban xuexiao xiehui de yijian tigang" (Proposal on Association of Non-Governmental Education Institutions), Minban jiaoyu dongtai (Development in Non-Governmental Education), No. 2, 2002, pp. 1-4. 17. Wu Weimin, op. cit.

18. Ibid.

\section{RÉSUMÉS}

The Chinese Communist Party (CCP) oversees the governance of public sector higher education institutions, and the Party's leadership is constitutionally assured. Most private education institutions, however, exist as corporations, and this legal status means that constitutionally the CCP is not part of the governing body. This paper first discusses the question, what is the absolute leadership of the Party in education'?, and then the issues surrounding the relationship between the CCP and the governing body in an institution of private education. Possible legal avenues are also examined to provide a new perspective on the role of the CCP in the private tertiary education sector. That the presence of the CCP in the private tertiary education sector is problematic reflects a political dilemma in current Chinese society: capitalist elements have been introduced to reform various aspects of economy and society, but the political system has remained unchanged. Can China implement further reforms without this affecting the political status quo? This discussion can be seen as a call for political reform. 